\title{
Environmental significance of Ophiomorpha in a transgressive- regressive sequence of the Spitsbergen Paleocene
}

\author{
Jenö Nagy, ${ }^{1}$ Francisco J. Rodríguez Tovar $^{2}$ \& Matías Reolid ${ }^{3}$ \\ 1 Department of Geosciences, University of Oslo, PO Box 1047 Blindern, NO-0316 Oslo, Norway \\ 2 Department of Stratigraphy and Paleontology, University of Granada, Campus Fuentenueva sn, ES-18071 Granada, Spain \\ ${ }^{3}$ Department of Geology, University of Jaén, Campus Las Lagunillas sn, ES-23071 Jaén, Spain
}

\section{Keywords}

Trace fossils; Paleocene; shoreface sandstones; brackish water; transgression signal.

\section{Correspondence}

Jenö Nagy, Department of Geosciences, University of Oslo, PO Box 1047 Blindern, NO-0316 Oslo, Norway.

E-mail: jeno.nagy@geo.uio.no

\begin{abstract}
The study focuses on occurrences of Ophiomorpha burrows in a transgressiveregressive succession composing the Early Paleocene Firkanten Formation deposited in paralic, prodelta to delta front conditions in the Central Basin of Spitsbergen. The burrows colonize sandstones of the Todalen Member at four sites and belong to two ichnospecies: Ophiomorpha cf. nodosa, forming dominantly vertical shafts; and $O$. cf. irregulaire, consisting of horizontal sinuous tunnels ending in subconical shafts. Both species are observed in shoreface sandstones deposited as a barrier bar. Lithological features and stratigraphic positions suggest that the trace-makers preferentially colonized high-energy sand environments. Foraminiferal faunas occurring below and above the barrier sandstones indicate brackish water conditions for the Ophiomorpha levels, which accordingly are of restricted, monospecific nature. It is inferred that the trace-makers had a dominantly suspension feeding habit as a modern analogue Calianassa major. Portrayed in a sequence stratigraphic framework, the Ophiomorpha-bearing sandstones in middle reaches of the Central Basin were deposited in the final stage of the transgressive systems tract, which drowned the underlying coal-bearing paralic facies. Moreover, in the northern, coal-rich parts of the basin, occurrence of Ophiomorpha signals marine ingression into the paralic system.
\end{abstract}

Two species of the ichnogenus Ophiomorpha are recognized in the Early Paleocene Firkanten Formation of the Paleogene Central Basin of Spitsbergen, the main island of the Arctic archipelago of Svalbard. Occurrences of these trace fossils in four sections are in this paper treated as paleoenvironmental and stratigraphic proxies.

Ichnologic research during the last century, with increasing intensity in the present one, led to the development of trace fossil analysis as a significant contributor to a wide range of fields, including palaeobiology, palaeoecology, biostratigraphy, palaeobathymetiry and sedimentology. During the last decade, a rapid expansion of this approach has significantly contributed to basin analysis (including allostratigraphy, cyclostratigraphy, genetic stratigraphy, sequence stratigraphy, etc.).
In sequence stratigraphy, trace fossil associations have been used to characterize discontinuity surfaces (particularly at sequence boundaries) mainly based on the recognition of substrate-controlled ichnofacies. Moreover, vertical changes in ichnologic features across the sequence architecture have been applied for characterizing parasequences, parasequence sets and system tracts. See recent reviews by Rodríguez-Tovar (2010) and Buatois \& Mángano (2011).

Ophiomorpha is a common trace fossil in Mesozoic and Cenozoic sedimentary rocks deposited in shallow and marginal marine environments, although some species have been registered in deeper marine settings (Frey et al. 1978). In shallow water deposits, Ophiomorpha is mainly represented by $O$. nodosa, while in deep-sea sediments 
O. rudis is most typical (Tchoumachenko \& Uchman 2001 and references therein).

The stratigraphic record left by the trace-makers is of special interest because of their adaptation to particular palaeoecological and depositional conditions, which make them very useful for environmental assessments, as well as for palaeobiological, neoichnological and evolutionary palaeoecological research; see de Gibert et al. (2006) for a review. Further support to these applications is provided by comparisons with modern analogous burrows of thalassinoidean crustaceans. Ophiomorpha is a substratecontrolled ichnotaxon, found mainly in fine- to mediumgrained sand deposits (Ekdale 1992).

The aims of the present study are: (1) to depict the morphology of Ophiomorpha species occurring in the Firkanten Formation, which will be the first illustrated documentation of this ichnogenus in the Cenozoic succession of the Barents Sea region; (2) to improve the application potential of these traces as stratigraphic and biofacies proxies in sandstone intervals commonly devoid of microfossils and macro-invertebrate remains; (3) to elucidate facies changes across a transgressive-regressive $(\mathrm{T}-\mathrm{R})$ sequence, exemplified by the coal-bearing Firkanten Formation of Spitsbergen.

\section{Geological setting}

The sedimentary infill of the Paleogene Central Basin of Spitsbergen (Fig. 1) is a succession up to $2300 \mathrm{~m}$ in thickness, consisting of siliciclastic mudstones and sandstones deposited in fluvial, deltaic to delta-influenced offshore shelf environments. This succession comprises the Paleogene Van Mijenfjorden Group (together with a small outlier at Kongsfjorden). A review of the Cenozoic geology of Spitsbergen is given by Harland (1997).

The Central Basin succession comprises Paleocene, Eocene and probable Early Oligocene deposits, which are subdivided into five formations with the main outcrop areas being south of Isfjorden (Dallmann et al. 1999). Within this succession, four $\mathrm{T}-\mathrm{R}$ sequences are distinguished (Nagy et al. 2013; Fig. 1). Based on foraminiferal facies, the Paleogene bathymetry of the Central Basin and the western Barents Sea was discussed by Nagy et al. (2000).

The main focus of this study is the Early Paleocene Firkanten Formation (Fig. 2), which composes the lowermost part of the Central Basin Tertiary succession and is well known for its commercially important coal deposits. The stratigraphy and depositional conditions of the formation were discussed in several papers including: Kellogg (1975), Steel et al. (1985) and Nøttvedt (1985) dealing with the sedimentology of the formation; and Nagy (2005) and Nagy \& Murray (2011) recording its foraminiferal stratigraphy and biofacies. The occurrence of Ophiomorpha traces was mentioned by Major \& Nagy (1972) and Nagy (2005) without closer documentation.

Because the Paleogene deposits of the Central Basin are poor in biostratigraphically significant fossils, their age relationships remain only roughly defined by deduction from a few adequately dated levels. Recent recognition of the Paleocene-Eocene Thermal Maximum in the Gilsonryggen Member of the Frysjaodden Formation dates this level as earliest Eocene (Cui et al. 2011). Therefore, the underlying Hollendardalen, Grumantbyen, Basilika and Firkanten formations belong to the Paleocene (Fig. 1). For the Basilika Formation, Manum \& Throndsen (1986) proposed an age corresponding to the transition between Early and Late Paleocene based on dinocysts.

The foraminiferal assemblages recorded from the Todalen and Kolthoffberget members of the Firkanten Formation (Nagy 2005; Nagy \& Murray 2011) are closely related to Paleocene faunas reported from the BeaufortMackenzie Basin of the Canadian Arctic by McNeil (1997) and provide further evidence supporting a Paleocene age for the Firkanten.

\section{The studied localities}

The main locality studied is the Basilikaelva section (Figs. 1, 3) where the Todalen Member exposes impressive occurrences of Ophiomorpha cf. nodosa and $O$. cf. irregulaire. It is located at the foot of the Basilika Mountain, in the stream bed and on the banks of an ephemeral creek, Basilikaelva, flanking the lateral moraine of Penckbreen. The section is $56 \mathrm{~m}$ thick and exposes the Todalen Member mainly in the stream bed and on its western bank. The lower and middle parts of the Kolthoffberget Member appear on the steep eastern bank. The remaining upper part of the Firkanten Formation is obscured by scree higher up on the gentle mountain slope.

The Kolfjellet section starts at the shore of Van Mijenfjorden and continues up the south-western slope of this mountain (Fig. 4a). For a lithological log, see Nagy (2005). The section is $84 \mathrm{~m}$ thick, but its lowermost ca. $10 \mathrm{~m}$ is partly covered at the shore. Supplementary observations of a corresponding interval were made on the nearby mountain slope north-west of the coastal exposure area. The section covers almost all of the Todalen Member and the whole of the Kolthoffberget and Endalen members, but only the Todalen and Kolthoffberget are logged. No ophiomorphid traces have been observed at this site, which however provided sedimentary features significant for facies assessments of the Firkanten Formation. 

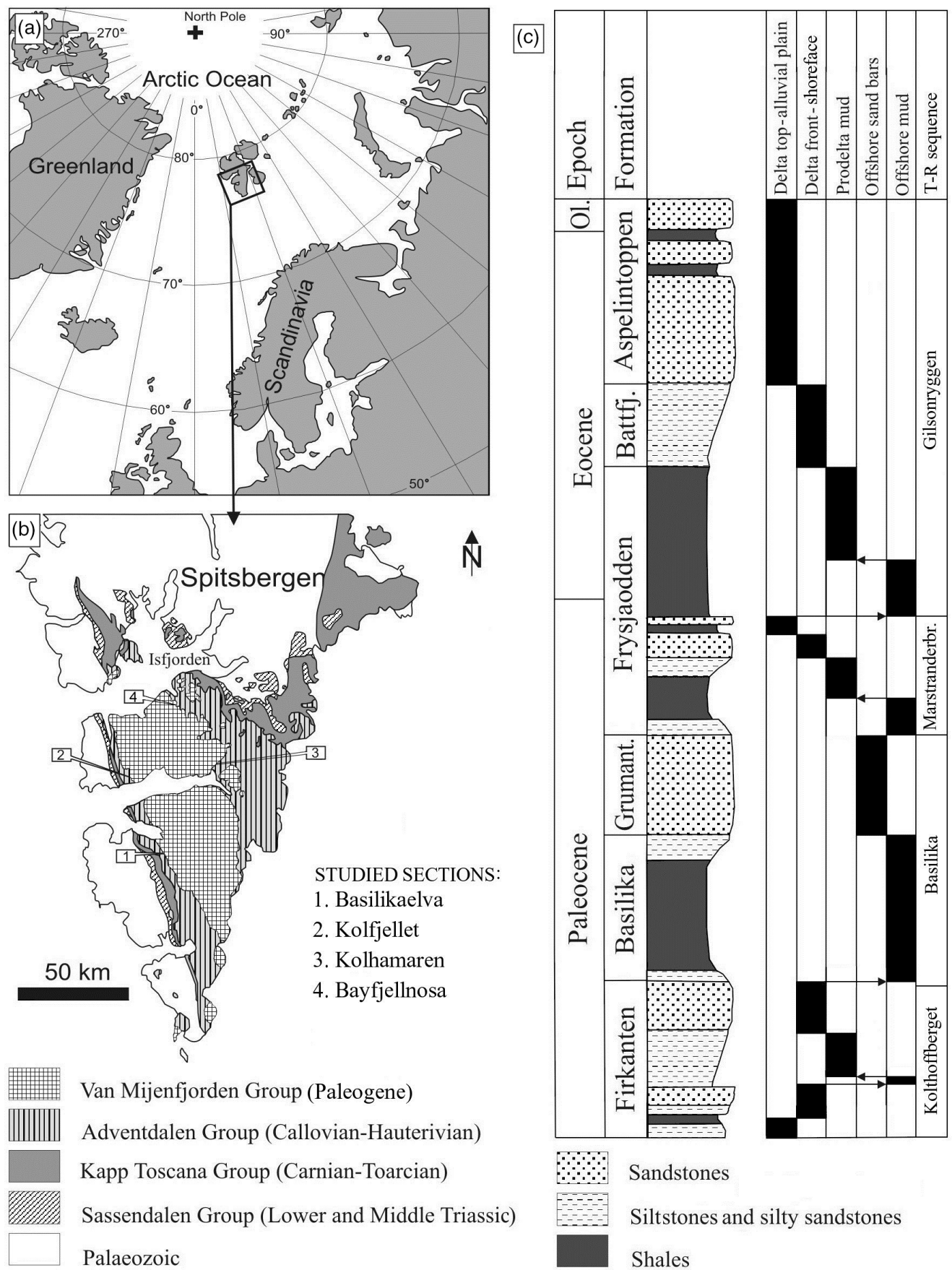

Fig. 1 (a) Location of Spitsbergen on the Svalbard Archipelago. (b) Geological map of central and southern Spitsbergen with position of the four studied localities. (c) Stratigraphic outline of the Spitsbergen Paleogene succession with lithological column and facies trends in a framework of transgressive-regressive (T-R) sequences.

The Kolhamaren section is located ca. $2 \mathrm{~km}$ east from the mining settlement Sveagruva, on the south-western corner of the mountain Kolhamaren. Here, a rich occurrence of $O$. cf. nodosa has been recognized in the coalbearing Todalen Member.
The Bayfjellnosa section shows the Firkanten Formation on the western slope of this mountain close to an abandoned coal mine entrance structure (Fig. 4c). A few burrows belonging to $O$. cf. nodosa have been observed in the Todalen Member on a cliff site. 


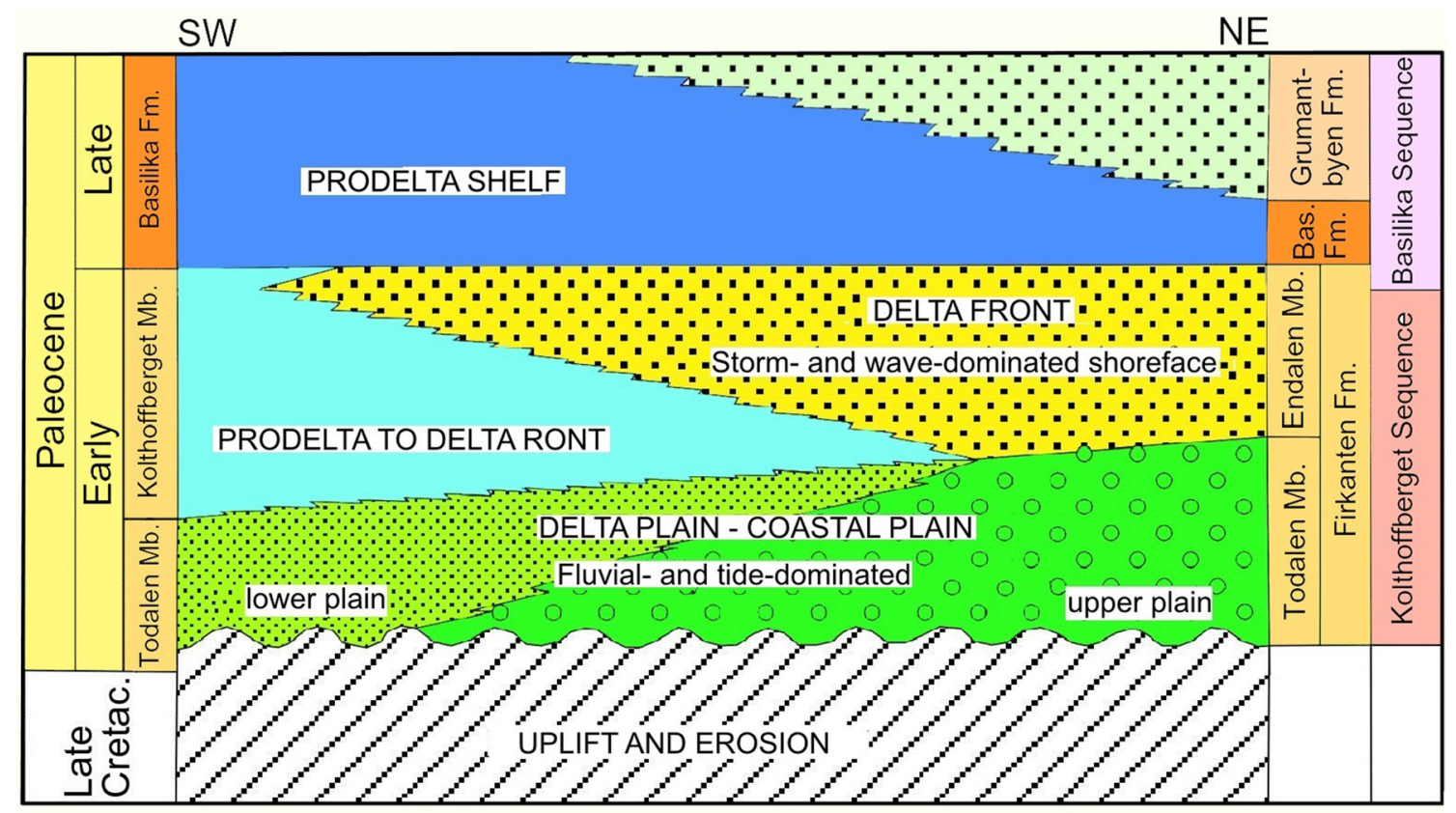

Fig. 2 Outline of the stratigraphy and depositional conditions of the Firkanten, Basilika and Grumantbyen formations in the Paleogene Central Basin of Spitsbergen along a south-west-north-east transect (modified from Steel et al. 1981; Nagy 2005).

\section{Stratigraphy of the Firkanten Formation}

The Firkanten Formation represents the Kolthoffberget $\mathrm{T}-\mathrm{R}$ sequence resting on Early Cretaceous deposits with a subaerial unconformity (Fig. 2). The formation is composed of the Todalen, Kolthoffberget and Endalen members, all of which are present in the southern and middle reaches of the Central Basin. Going northwards, the mudstone-dominated Kolthoffberget Member wedges out, so in northern regions only the sandy Todalen and Endalen members occur (Fig. 4c). These relationships and changing thicknesses suggest that the member boundaries are regionally diachronous across the basin (Nagy 2005).

The Todalen Member starts with an erosive conglomerate marking the basal boundary of the Kolthoffberget Sequence. The member is dominated by sandstones, siltstones and shales deposited in delta plain, coastal plain to marginal marine environments (Fig. 2). In southern and south-western parts of the Central Basin, the member is strongly influenced by marine processes, while in the northern parts alluvial and deltaic processes are dominant and controlled the extensive coal formation (Steel et al. 1981). In the Basilikaelva section, the upper part of the member is a sandstone unit with Ophiomorpha burrows.

The deposition of the overlying Kolthoffberget and Endalen members was principally controlled by progradation of a large coalesced delta system (Nøttvedt 1985; Nagy 2005). The Kolthoffberget Member is essentially a prodelta succession dominated by shales and siltstones.
The Endalen Member is composed of delta front sheet sandstones deposited in storm- and wave-dominated shallow water and constitutes the final stage of the Kolthoffberget Sequence.

In the Basilikaelva section, the Firkanten Formation is subdivided into four facies units, which are described below as stratigraphic intervals lettered from A to D (Fig. 3) and further discussed in a later chapter. The units are recognized throughout the outcrop area stretching from the Basilika to the Kolthoffberget sites and appear to be typical for middle reaches of the basin.

Interval A. This unit comprises the lower part of the Todalen Member with a thickness of $6.5 \mathrm{~m}$ in the Basilikaelva and $16.6 \mathrm{~m}$ in the Kolfjellet section (Nagy 2005). Its deposition started with the Grønfjorden Bed basis conglomerate, which has a thickness of 0.6 to $1.0 \mathrm{~m}$ in the Basilikaelva section, where it rests on a rough erosional surface cutting the Early Cretaceous Carolinefjellet Formation (Fig. 3). At Basilikaelva, the conglomerate is overlain by laminated dark shales containing fossil leaves belonging to Metasequoia and Ginkgo. At Kolfjellet, siltstones and sandstones dominate the correlative interval, and several coal seams are present (Fig. 5d). In the Bayfjellnosa section, the Todalen Member is $35 \mathrm{~m}$ thick and contains several coal seams (Fig. 4c).

Interval B. This comprises the middle part of the Todalen Member with a thickness of $12 \mathrm{~m}$ in the Basilikaelva and 


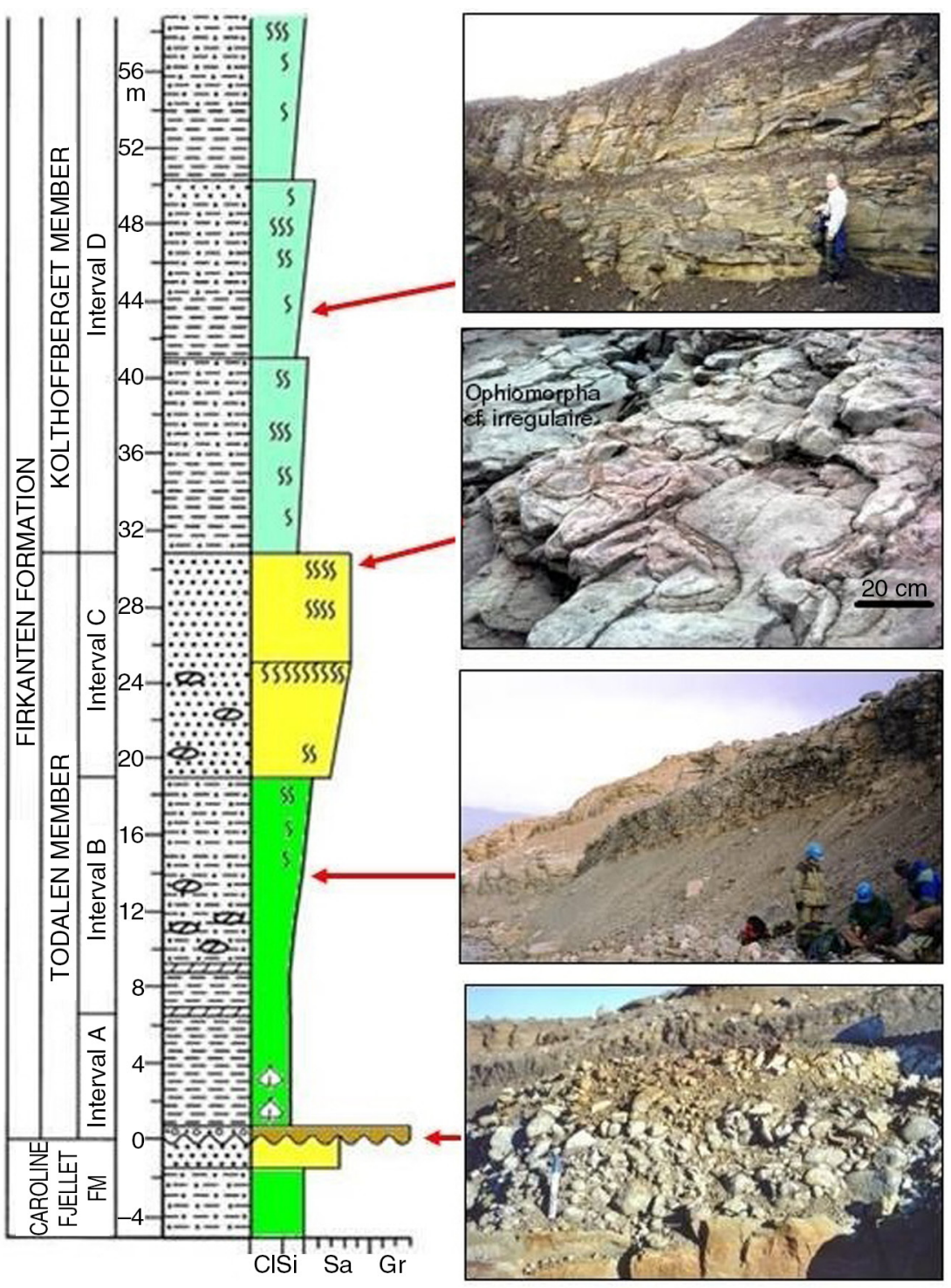

Fig. 3 Lithological column of the Firkanten Formation in the Basilikaelva section, with field photographs of typical features.

$17.5 \mathrm{~m}$ in the Kolfjellet section. The dominant lithologies are blocky- to prismatic-weathering grey shales and siltstones forming a coarsening-upwards trend. Siderite beds and concretions are common in the lower part (Fig. 3), while the total organic carbon content is generally low $(0.4-1.7 \%)$.

Interval C. The top of the Todalen Member is a distinct sandstone unit having a thickness of $14 \mathrm{~m}$ in the Basilikaelva and $10 \mathrm{~m}$ in the Kolfjellet section. It consists of homogeneous, medium-grained, well-sorted sandstone from yellowish grey to white colour. Scattered coaly plant fragments are present. The basal contact of the interval is gradational, and its lower part is essentially a coarsening- upward succession from shale through siltstone to sandstone, continuing to the sharp top contact (Fig. 4a, d).

Sedimentary structures are difficult to recognize within the sandstone interval. Exceptions are discrete levels in the upper part, containing wave- and current-generated ripples (Figs. 4b, 5a). In the Kolfjellet section, the upper $60 \mathrm{~cm}$ of the interval reveals slightly inclined plane parallel lamination (Fig. 5c).

Interval $\mathrm{C}$ is extensively exposed in the Basilikaelva section where it includes three characteristic horizons containing trace fossils. The lowest one, located $6 \mathrm{~m}$ above the base, is densely colonized by mainly vertical burrows of Ophiomorpha cf. nodosa. The second level occurs around $8.5 \mathrm{~m}$ above the base and contains scattered $O$. cf. nodosa. 

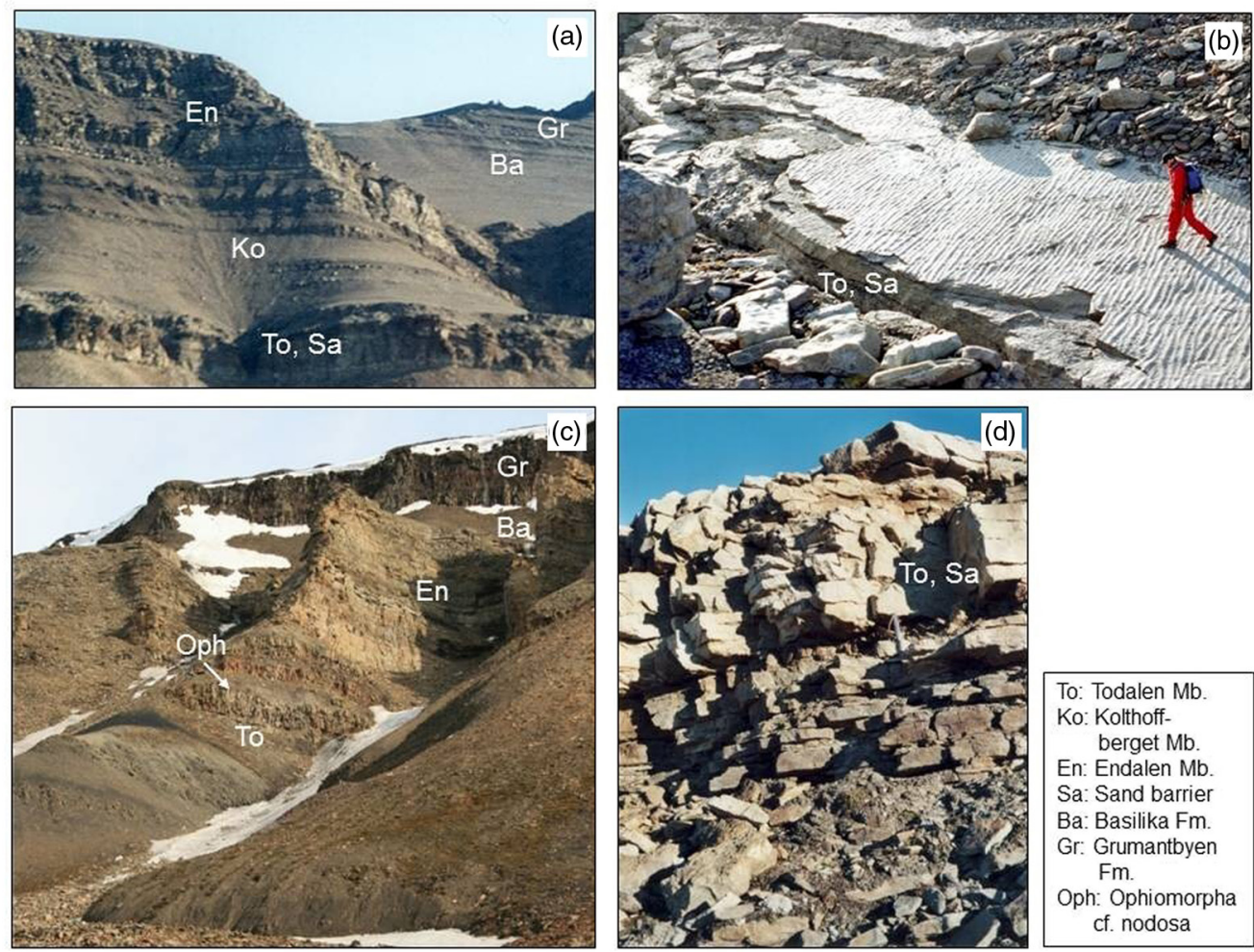

Fig. 4 Sedimentary features of the Firkanten Formation and overlying units. (a) Middle and upper part of the Firkanten Formation, Kolfjellet section. (b) Wave-generated ripples on a bedding plane near the top of unit C, Basilikaelva section. (c) The Todalen and Endalen members of the Firkanten Formation, and the overlying Basilika and Grumantbyen formations, Bayfjellnosa section. (d) Coarsening-upward sandstone interval forming the lover and middle part of unit C, Basilikaelva section.

The third level is located $60 \mathrm{~cm}$ below the top of the unit, close to a well-exposed rippled bedding plane. It contains a mass occurrence of large burrows of $O$. cf. irregulaire lying parallel to the bedding surfaces.

Other ichnofossils observed at the Basilikaelva site are a few specimens of Rhizocorallium occurring in the upper part of this interval. In addition, internal molds of large bivalve shells and impressions of bivalves (resting traces) are present on bedding plains.

Interval D. This unit represents the Kolthoffberget Member, which consists mainly of shale and siltstone, and shows an overall upwards-coarsening development (Fig. 3). It is formed of repeated parasequences, each of which typically starts with shale or silty shale and terminates in siltstone or fine-grained sandstone (Fig. 4a). These lithologies display intense bioturbation, particularly pronounced in the siltstone and sandstone beds. Horizontal traces similar to Planolites are the most common. The organic carbon content varies from 0.8 to $1.9 \%$ (average $1.4 \%$ ) at Basilikaelva, and from 0.5 to $1.5 \%$ (average $1.1 \%$ ) at Kolfjellet.

\section{The Spitsbergen Ophiomorpha species}

The diagnosis of the ichnogenus Ophiomorpha Lundgren 1891 refers to burrow systems of simple to complex architecture lined partially or wholly with pellets of agglutinated sediment (Howard \& Frey 1984; Uchman 1998). Ichnospecies of Ophiomorpha are mainly differentiated on the basis of geometric configuration combined with features of the pelletal burrow lining (see revisions by Uchman [1999, 2009]).

The trace fossils recognized in the Todalen Member are assigned to Ophiomorpha owing to their general shape and the presence of more or less distinct pelletal lining of the burrow walls. On the species level, they are provisionally designated by open nomenclature.

\section{Ophiomorpha cf. nodosa Lundgren 1891}

This ichnospecies is represented by vertical, slightly oblique and rarely bending shafts. In cross-section the shafts are circular, $1.0-1.4 \mathrm{~cm}$ in diameter and have a roughly crenulated outline (Figs. 5b, $6 a-d, 8)$. The exterior 

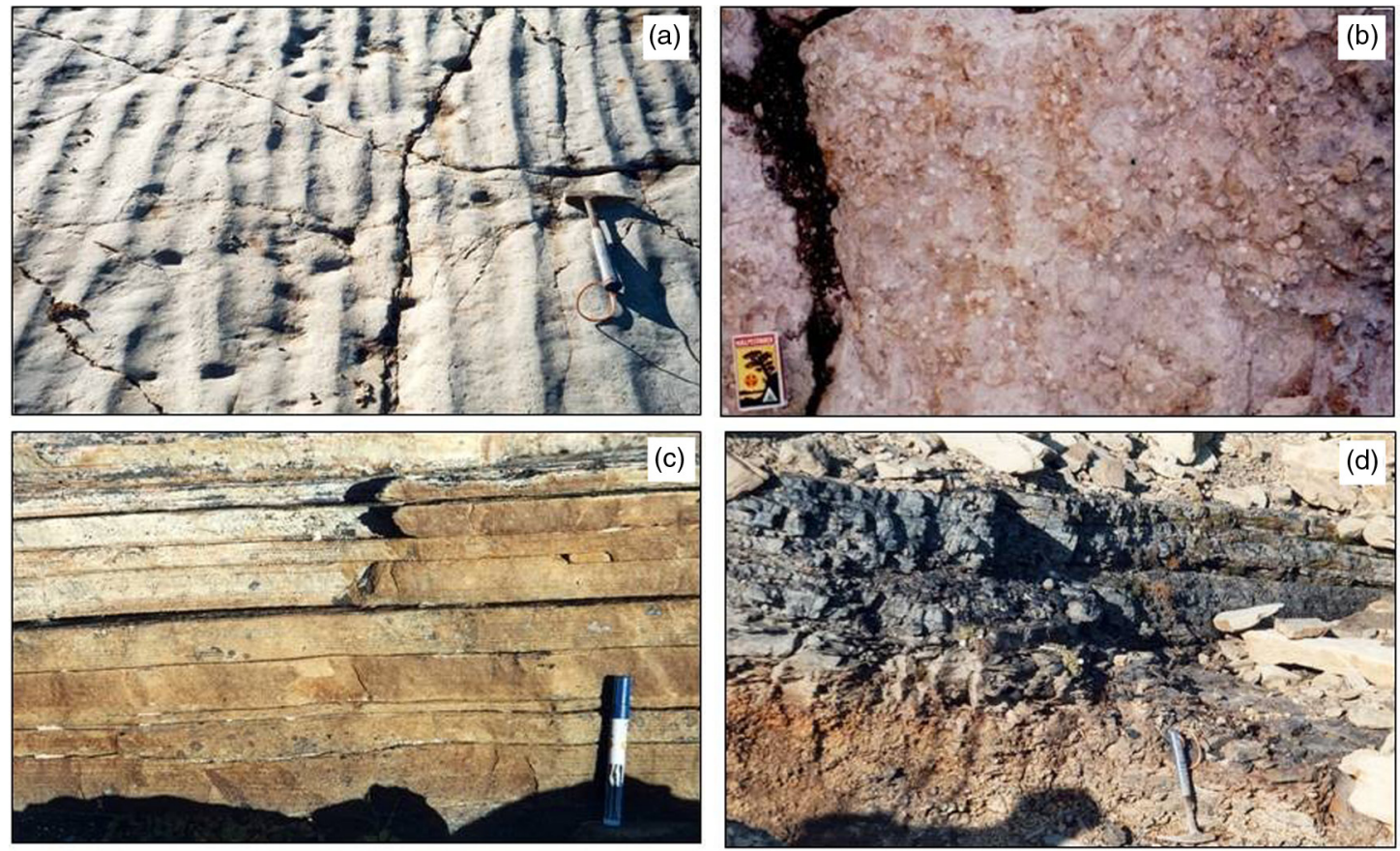

Fig. 5 Sedimentary and biotic features of the Firkanten Formation. (a) Current-generated ripples and bivalve impressions on a bedding plane near the top of unit C, Basilikaelva section. (b) Dense population of Ophiomorpha cf. nodosa shafts cut horizontally by a bedding plane in unit C, Basilikaelva section. (c) Sandstone with low-angle parallel lamination indicating foreshore deposition at the top of unit C, Kolfjellet section. (d) Coal seam in unit A, Kolfjellet section.

of the shafts is covered by irregularly spaced low subconical to spike-like projections (visible at the burrow-tosediment contact) regarded as deformed pellets. These pelletal surfaces commonly have a very thin veneer of grey to black material. Among described species, the Spitsbergen form appears most similar to O. nodosa.

According to previous studies, $O$. nodosa refers to structures of vertical shafts and branching tunnels forming a horizontal meander maze (e.g., Pickett et al. 1971; Frey 1975; Bromley \& Pedersen 2008). Its pelletal wall lining is usually composed of robust, rounded tubercles varying in shape from ovoid to irregularly polygonal (Frey et al. 1978; Bromley 1991; Miller et al. 1998). In the Spitsbergen material, horizontal tunnels and branched burrows are not observed.

The morphology of pellets is a diagnostic feature in distinguishing ophiomorphid taxa. In the Spitsbergen material, the original shape of the pellets is hard to assess. The conical and spiky structures of the pelletal lining can be explained by physical compression during early diagenetic compaction of the sediment. Comparable spiky pelletal surfaces in $O$. irregularie are reported by Bromley $\delta$ Pedersen (2008) and Boyd et al. (2012), who explained these extensional attenuations by sediment compaction.

According to Frey et al. (1978), the matrix cementing the sandy pellets of $O$. nodosa consists of clay minerals with iron oxides and sulphides. In the Bayfjellnosa section, the presence of iron compounds is signalled by the red colour of the pelletal lining of $O$. cf. nodosa (Fig. 6c).

The apparent absence of horizontal tunnels and branching burrows requires additional observations based on new fieldwork. The significance of the small shaft diameters should also be addressed. The closer clarification of the prediagenetic pelletal morphology is particularly necessary for deciding the proper taxonomic status of $O$. cf. nodosa on the species level.

In the Central Basin, $O$. cf. nodosa is observed at three localities: (1) a mass occurrence in the Todalen Member of the Basilikaelva section at a horizon located $6 \mathrm{~m}$ above the base of interval $\mathrm{C}$, and scattered burrows $8.5 \mathrm{~m}$ above the base of this unit composed of barrier bar sandstones; (2) a mass occurrence in sandstones of the Todalen Member of the Kolhamaren site; (3) scattered burrows in sandstones of the Todalen Member in the Bayfjellnosa section.

\section{Ophiomorpha cf. irregulaire Frey et al. 1978}

This ichnospecies is assigned to thick burrows mainly of meandering shape, but coiled, subcircular, sinuous or more irregularly bent forms also occur (Figs. 7a-d, 8). All of them are subhorizontal, lying parallel to the bedding planes. The cross-section of the tunnels is subelliptical 

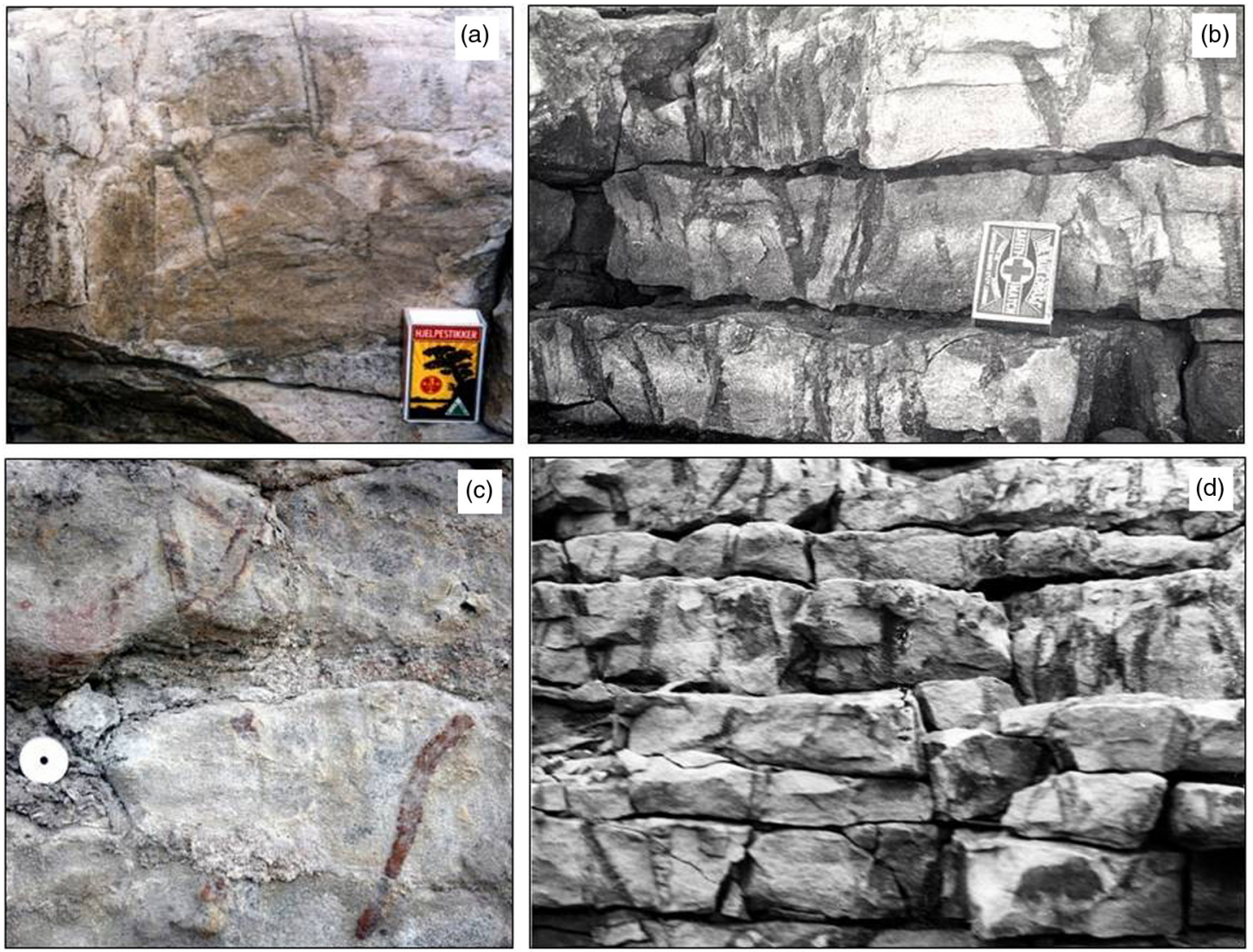

Fig. 6 Field photographs of Ophiomorpha cf. nodosa from the Firkanten Formation. (a) Sparsely-spaced shafts from the middle part of unit C, Basilikaelva section. (b, d) Dense population of shafts in the upper part of unit C, Basilikaelva section. (c) Sparsely scattered shafts in a sandstone bed of the Todalen Member, Bayfjellnosa section.

with a larger diameter ranging from 5.0 to $7.0 \mathrm{~cm}$, but the original, pre-diagenetic outline was probably circular. Some more complete specimens show an upward-bending subconical initial projection which apparently formed a vertical or inclined shaft probably of short extent, connecting the tunnel with the sea floor (Fig. 7a). Branching is not observed. The sand fill of the tunnels shows an irregular bumpy surface which in non-weathered specimens is partly covered by a film of a dark substance apparently enriched in clay minerals (Fig. 7b, c).

Ophiomorpha irregulaire was originally named and described by Frey et al. (1978), followed by an emended diagnosis published by Bromley \& Ekdale (1998). According to these studies, the geometry of $O$. irregulaire is a predominantly horizontal system forming a meander maze composed of smoothly curved internodal tunnels with an oval cross-section. Typical features are T- and Y-shaped branching nodes. The roof lining is pelletal, consisting of regularly or irregularly spaced conical to attenuated outwardly tapering pellets of non-uniform size. The interior surface of the lining is smooth.
In the Spitsbergen occurrences, the pelletal lining of $O$. cf. irregulaire is represented by the dark film preserved on non-weathered surfaces and visible as a thin dark layer between the tunnel fill and the surrounding sandstone. The outer surface of this layer reveals indistinct spiky to subconical projections appearing at the burrow-tosediment contact (Fig. 7c, d), similar to those depicted by Bromley $\&$ Ekdale (1998) in their redescription of $O$. irregulaire. Sand-filled pellets and flame-like extensions, comparable to features recorded by Boyd et al. (2012), are not observed.

The weathered surface of some Spitsbergen specimens and the surrounding sandstone are coloured red to brown by iron oxide-hydroxide (Fig. 7a). It accords with Frey et al. (1978), reporting presence of iron oxides and sulphides in the pelletal matrix of Ophiomorpha. Enrichment in organic substances might contribute to the dark colour of the lining, visible on more fresh surfaces.

Relatively few examples of $O$. irregulaire have been published from outcrops, compared with its extensive record from drill cores where its specific identification has 

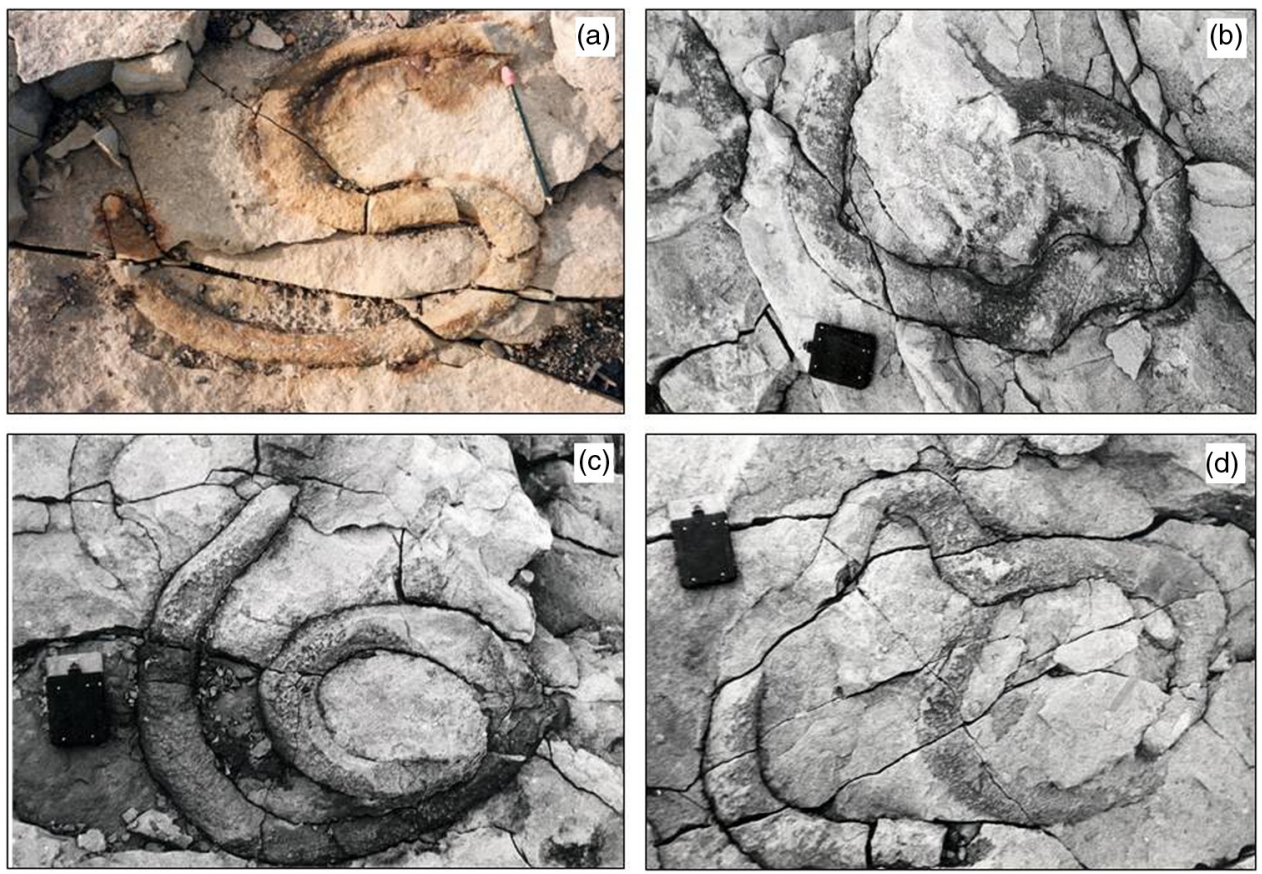

Fig. 7 Field photographs of Ophiomorpha cf. irregulaire parallel to a bedding plane $60 \mathrm{~cm}$ below the top of unit C, Basilikaelva section. (a) Single sinuous tunnel with upwards-bent base of constricted subvertical shaft at the left hand end. (b, c, d) Coiled and somewhat irregularly bending tunnels showing an uneven, low bumpy surface and dark lining at the contact between the tunnel and surrounding sediment.

a varying degree of precision (Bromley \& Pedersen 2008). However, the species has been described without doubt from outcrops of the Late Cretaceous in Utah (USA) and East Greenland, and from the Jurassic in Italy. Based on detailed reconstructions, Boyd et al. (2012) regarded $O$. irregulaire as a cosmopolitan ichnospecies.

Among well-documented O. irregulaire, the Spitsbergen species is most similar to specimens figured by Frey et al. (1978), Bromley \& Ekdale (1998) and Bromley \& Pedersen (2008). However, the Spitsbergen form differs from these records by its uniformly bending tunnel geometry, lacking branching to form a meander maze, and having a single upward-bending constricted termination; features suggesting that it might be a new ichnospecies. Apparent absence of sand-filled pellets, reported by Boyd et al. (2012) as diagnostic of $O$. irregulaire, is also relevant in this connection. Until now, the single documented observation of $O$. cf. irregulaire is its mass occurrence in the Todalen Member of the Basilikaelva section $60 \mathrm{~cm}$ below the top of unit $\mathrm{C}$ interpreted as barrier bar sandstone.

\section{Morphology of other ophiomorphid taxa}

The comparisons discussed above demonstrate that the morphologies of the two Spitsbergen ichnspecies are closely related to Ophiomorpha nodosa and O. irregulaire.
Some less diagnostic similarities exist between the Spitsbergen forms and several other ophiomorphid species, as follows.

Ophiomorpha borneensis Keij 1965 is typified by burrow walls consisting predominantly of dense, regularly distributed bilobate pellets. Ophiomorpha annulata Ksiazkiewicz 1977 refers to mainly horizontal to subhorizontal, cylindrical, rarely branched structures with elongated wall granules arranged perpendicularly to the burrow axes. Ophiomorpha recta Fischer-Ooster 1858 forms mostly horizontal or subhorizontal burrows, rarely branched, with small muddy pellets on the margin of the tube. Ophiomorpha rudis Ksiazkiewicz 1977 is composed of mostly oblique shafts and straight or slightly winding branched horizontal tunnels, with walls covered at least partly by irregular granules and unevenly spaced scratch traces commonly replaced by longer smooth intervals. Ophiomorpha puerilis de Gibert et al. 2006 is a small, rectilinear ichnospecies, in some cases ending in a slightly enlarged chamber, with a lining formed of a single layer of cylindrical pellets with rounded ends. Ophiomorpha beaumarisensis Ter $\&$ Buckeridge 2012 is a recent ichnospecies composed of tubular anastomosing burrows with a granulated, finely nodose external surface, and with a diameter almost twice that of $O$. nodosa and considerably more branching. 


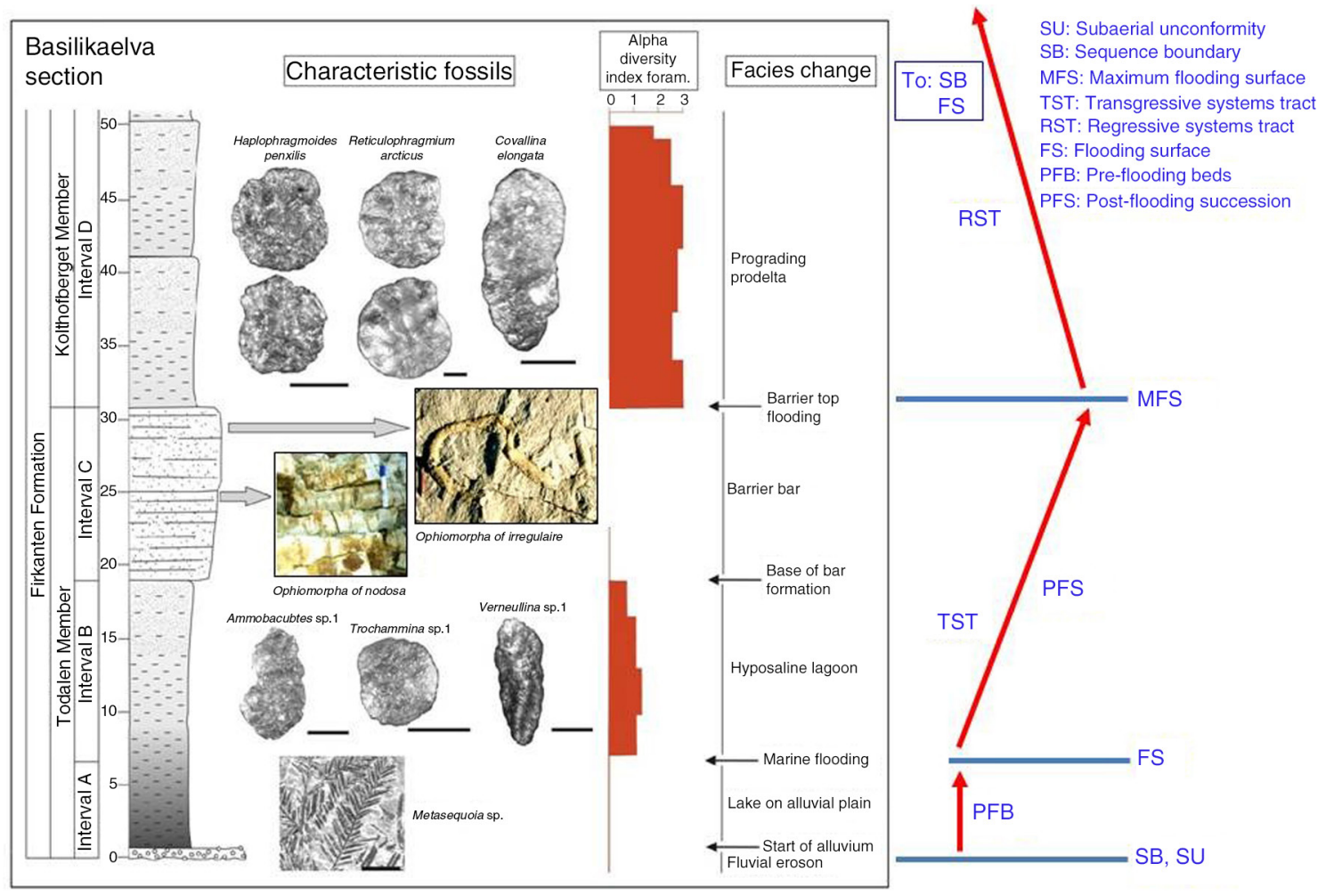

Fig. 8 The Firkanten Formation in the Basilikaelva section with typical fossils, foraminiferal diversity index and succession of depositional facies changes in a transgressive-regressive sequence stratigraphic framework. The Ophiomorpha burrows are observed in the barrier bar sandstones (Unit C), while low-diversity agglutinated foraminiferal assemblages occur in the shales below and above. (Scale bars with foraminifera $250 \mu \mathrm{m}$.)

\section{The Firkanten facies succession with Ophiomorpha levels}

Lake and coal swamps on alluvial plainInterval A. In the Basilikaelva section, the basis conglomerate of the Todalen Member reveals a clast content with well-developed imbrication, resting on a rough erosional surface reflecting deposition in a high-energy fluvial environment (Figs. 3, 8). For the overlying shale package, lacustrine conditions on an alluvial plain are suggested by the fine-grained lithology, presence of lamination, occurrence of well-preserved plant leaves and absence of foraminifera and other marine indicators. Presence of a laterally nearby coal seam is in accordance with alluvial plain conditions. At Kolfjellet, siltstones, shales and sandstones dominate this interval, and the presence of several coal seams indicates swamp environments (Fig. 5d).

Intermittent transgression on alluvial plainBayfjellnosa and Kolhamaren. In the northern part of the Central Basin, the Todalen Member of the Bayfjellnosa section (Fig. 4c) consists mainly of deltaic and alluvial plain deposits including several coal seams. Ophiomorpha cf. nodosa is observed in a sandstone bed between two coal seams and indicates a short episode of marine transgression into the paralic system. In the Kolhamaren section, mass occurrence of $O$. cf. nodosa occurs close to a coal seam.

Hyposaline Lagoon-Interval B. In the Basilikaelva and Kolfjellet sections, this interval of blocky-weathering shales contains entirely agglutinated foraminiferal assemblages of extremely low diversity suggesting restricted environmental conditions in a lagoon sheltered by the transgressively overlying sand barrier (Fig. 8). Low salinity is assumed to be the main restricting factor in the lagoonal waters as also indicated by strong dominance of the opportunistic genera Trochammina, Ammobaculites and Verneuilina. Other common genera include Placentammina, Crithionina, Convallina and Psammosphaera (Nagy \& Murray 2011).

Barrier bar-Interval C. This discrete sandstone unit separates the strongly restricted foraminiferal facies of interval B from the less restricted foraminiferal facies of interval $\mathrm{D}$ as indicated by the foraminiferal diversity (Fig. 8). In a transgressive setting, this stratigraphic position suggests a barrier bar origin together with the 
coarsening-upward development shown by the lower part of this sandstone unit (Fig. 4d). The clean-washed well-sorted nature of the sandstones corroborates with deposition in a shoreface environment. Wave- and current-generated ripples are common in the upper part (Figs. 4b, 5a). Locally, the sand bar was built up into the foreshore zone as indicated by occurrence of a low-angle cross-laminated bed forming the top of the interval in the Kolfjellet section (Fig. 5c).

As shown above, findings of Ophiomorpha cf. nodosa and $O$. cf. irregulaire in the Basilikaelva section are restricted to interval C. For this sandstone unit, brackish water depositional conditions are suggested by the occurrence of low-diversity brackish water agglutinated foraminiferal assemblages in the shales both below and above.

Prodelta-Interval D. This is a prodelta succession, belonging to the Kolthoffberget Member, that formed during outbuilding of the delta front sandstone succession composing the Endalen Member (Steel et al. 1985). The stacked parasequences composing the interval with upward increasing sand content reflect progradation of the delta system (Fig. 4a). The foraminiferal content of the prodelta beds is exclusively agglutinated and of low diversity, suggesting brackish conditions in the prodelta waters (Nagy \& Murray 2011). Dominant genera are Reticulophragmium, Convallina and Haplophragmoides (Fig. 8). Other common genera include Trochammina, Psammosphaera, Verneuilinoides and Crithionina. The most abundant and characteristic species are Haplophragmoides perexilis and Reticulophragmium arcticum.

\section{Environmental significance of Ophiomorpha burrows}

The middle and upper parts of the barrier sandstone unit C, with the Ophiomorpha traces, consist of well-sorted, fine- to medium-grained sandstones with very low organic carbon content. Typical sedimentary structures are well developed, mainly wave-generated ripples covering extensive bedding planes (Fig. 4b). In the Kolfjellet section, the sandstone beds forming the topmost $60 \mathrm{~cm}$ of the barrier unit reveal distinct parallel lamination, indicating foreshore depositional conditions (Fig. 5c). Thus, the stratigraphic position and associated sedimentary structures suggest a shoreface environmental setting for the Ophiomorpha burrows in unit C, which is in accordance with the environments of modern analogues.

An outline of the trophic strategies within modern callianassid crustaceans is given by Bromley (1996), and includes deposit and suspension feeding and bacterial gardening. Among several cited taxa, Callianassa major is documented as a suspension feeder, C. californensis and $C$. biformis are regarded as deposit-feeders, while Upobegia pugettensis is considered a suspension feeding gardener.

The morphologically closest modern analogues to fossil ophiomorphids are the burrows made by the shrimp-like crustacean Callianassa major. It lives along medium-energy coastlines of the south-eastern USA, burrowing in this stressful loose sandy habitat, mainly below mean low tide level (Frey et al. 1978; Bromley 1996). As shown by its faecal pellets, C. major is a suspension feeder. Its tunnels and shafts excavated in sands affected by waves and currents, primarily serve as protection in an unstable environment (Pryor 1975). This mode of life is in accordance with the clean, organic-poor sandstones composing the middle and upper parts of barrier bar unit $\mathrm{C}$ in the Basilikaelva section, as well as the sandstones at the Kolhamaren and Bayfjellnosa sites.

In the Basilikaelva section, Ophiomorpha cf. nodosa and $O$. cf. irregulaire occur at separate stratigraphic levels, while in the two other sections only $O$. cf. nodosa is found. All of the five observed assemblages form monospecific levels, which suggest an opportunistic behaviour of trace-makers adapted to a certain degree of environmental restriction. Ophiomorpha cf. nodosa occurs in more fine-grained sandstone than $O$. cf. irregulaire, which might point to a preference for different trophic resources or for somewhat different water energy.

Ophiomorphid species showing a dominance of vertical shafts characterize higher energy environments, while those composed mainly of horizontal mazes typify lower energy conditions (Frey 1975; Mude 2011). The morphology of the Spitsbergen $O$. cf. nodosa belongs to the first category, while that of $O$. cf. irregulaire is closer to the second type. The occurrence of $O$. cf. nodosa in finergrained sediments here therefore seems anomalous.

Ophiomorpha nodosa is globally widespread with high abundance in marginal marine and shallow marine sand environments. It also colonized tidal and estuarine channel deposits exemplified by the Miocene of Delaware, where it occurs both in marginal and axial channel strata (Miller et al. 1998 and references therein).

In Paleocene times, the Arctic Ocean waters were brackish owing to the restricted nature of the Polar Basin, having only shelf sea connections with the world ocean (McNeil 1990; Nagy 2005). In marginal extensions of this ocean, as in the Spitsbergen Central Basin, the brackish nature of the water column was further amplified by the closeness of fluvio-deltaic systems (Nagy et al. 2013).

The Basilikaelva section shows that the Ophiomorphabearing shoreface sandstones rest on brackish lagoonal shales and are overlain by brackish prodelta shales (Fig. 8). It is reasonable to assume that the salinity in the shoreface zone was even more reduced than in these deeper water 
mud deposition settings. The low salinity tolerance of $O$. cf. nodosa is further supported by its occurrence in a coalbearing paralic system at Bayfjellnosa and Kolhamaren, as well as the above-mentioned estuarine Delaware occurrences.

\section{Ophiomorpha in a sequence stratigraphic context}

The Kolthoffberget T-R sequence comprising the Firkanten Formation is a third order sequence according to the ranking system of Embry (2009). The sequence is composed of two systems tracts (Figs. 8, 9): the transgressive systems tract includes the pre-flooding beds, a post-flooding succession and the maximum flooding surface; the regressive systems tract is formed by a delta progradation succession terminating at the upper sequence boundary.

\section{Transgressive systems tract}

Pre-flooding beds. This stage starts with the Grønfjorden Conglomerate Bed (Fig. 3), which was deposited on a paleotopography formed during subaerial exposure. It is a distinct ravinement surface associated with a major hiatus extending over the whole Central Basin where the Late Cretaceous is missing. The pre-flooding beds (interval
A) are principally equivalent to the incised valley fill of the lowstand systems tract in the nomenclature of the Exoon (Van Wagoner et al. 1988) sequence stratigraphic model.

In the Basilikaelva section, the ravinement conglomerate is overlain by dark shales forming the main body of interval A, and is interpreted as a lake deposit (Nagy 2005) on an alluvial coastal plain. The presence of wellpreserved leaves suggests adjoining vegetated areas. Encroachment of the sea over the alluvial plain is marked by an initial flooding surface forming a siderite bed.

In northern and north-eastern parts of the Central Basin at Bayfjellnosa and Kolhamaren, the initial flooding is marked by sandstone beds containing Ophiomorpha cf. nodosa. In this region, coal seams are present both below and above the Ophiomorpha levels, as also reported by Major \& Nagy (1972). Correlation of these levels with the Basilikaelva and Kolfjellet sections requires further field observations.

Post-flooding succession. In the Basilikaelva section, the flooding event transformed the lake (interval A) to a hyposaline lagoon where the shales of interval $\mathrm{B}$ were deposited (Figs. 8, 9). The flooding led to development of low-diversity agglutinated foraminiferal assemblages of restricted nature. The lagoon was separated from open prodelta shelf waters by a barrier bar of fine- to medium-grained sand that formed interval $\mathrm{C}$, deposited

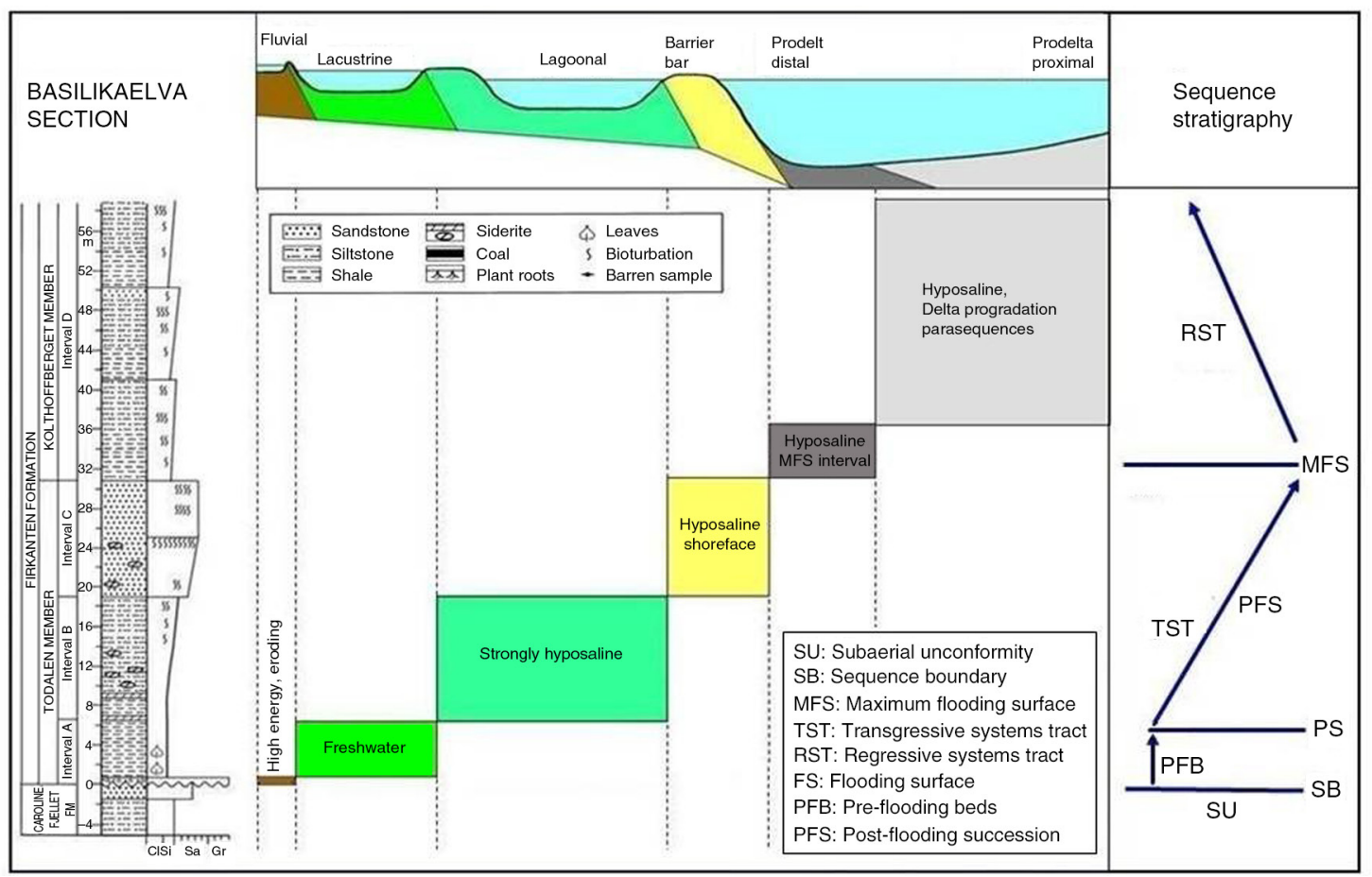

Fig. 9 Depth to distance diagram outlining facies succession of the Firkanten Formation in the Basilikaelva section portrayed in the framework of the Kolthoffberget transgressive-regressive sequence. The transgression advanced from south-west to north-east. 
during the advancing transgression. The shoreface sands on the seaward side of the barrier were intermittently colonized by Ophiomorpha cf. nodosa and $O$. cf. irregulaire at separate levels.

The Ophiomorpha-bearing beds were deposited in the final phase of the transgression, which terminated the coal-bearing paralic depositional regime in the Basilikaelva and Kolfjellet area. This flooding was of regional nature and marks the contact between the paralic Todalen Member and the prodelta Kolthoffberget Member in southern and middle reaches of the Central Basin (Fig. 2).

In northern and north-eastern parts of the Central Basin, the Todalen Member is much thicker than further south and contains coal seams both below and above an initial flooding event with Ophiomorpha. Moving northwards, the Kolthoffberget shales wedge out and the Endalen sandstones rest directly on the paralic Todalen Member. Defining the boundary between these members is important because it represents the upper limit of potential coal formation.

Maximum flooding surface. The abrupt change in lithology from sandstone to silty shale at the boundary between the Todalen and Kolthoffberget members (intervals $C$ and $D$, respectively) is just below the termination of the transgressive development. The lithological change displays a transgressive surface formed by flooding of the barrier reflected by foreshore lamination in the Kolfjellet section (Fig. 5c). This surface is overlain by a thin transitional bed which is immediately succeeded by the maximum flooding surface forming the lower part of the first coarsening-up parasequence introducing the Kolthoffberget Member (Fig. 8).

\section{Regressive systems tract}

Delta progradation. The regressive systems tract of the Kolthoffberget Sequence is comprised of the Kolthoffberget and Endalen members. The repeated parasequences typifying the Kolthoffberget reflect pulses of delta progradation into prodelta waters (Fig. 4a). The succeeding Endalen Member consists of delta front sandstones deposited during the final stage of the regression.

Sequence boundary. Outbuilding of the delta system terminates at the upper sequence boundary which shows a regionally varying development. In northern reaches of the Central Basin, it is marked by a conglomeratic level at the top of the Endalen Member. The conglomerates are well-exposed in Bjørndalen (close to Longyearbyen) and represent a ravinement surface. In middle reaches of the basin (e.g., at Basilikaelva), the corresponding level is developed as a sandstone to shale transition and forms a correlative conformity to the ravinement in the north.

\section{Conclusions}

In the Todalen Member of the Early Paleocene Firkanten Formation, two ophiomorphid species are recognized. Ophiomorpha cf. nodosa occurs mainly as vertically oriented, subcylindrical shafts. It has been observed in the Basilikaelva, Bayfjellnosa and Kolhamaren sections. The large-sized $O$. cf. irregulaire forms sinuous horizontal tunnels with constricted initial shafts. It has been observed only in the Basilikaelva section. The pelletal lining of both species appears as irregular spiky to attenuated subconical extensions.

Sedimentary features and stratigraphic position of the Ophiomorpha-bearing sandstones of the Basilikaelva section suggest deposition on the shoreface of a sand barrier. This setting corresponds to the habitat of a modern analogue, the shrimp-like crustacean Calianassa major, living in burrows made in high-energy coastal marine sand environments.

The monospecific nature of the Spitsbergen Ophiomorpha assemblages suggests opportunistic colonization behaviour under restricted environmental conditions. Brackish water in these habitats is indicated by the restricted nature of foraminiferal faunas occurring below and above the shoreface sandstones with Ophiomorpha at Basilikaelva, as well as by the delta-influenced background environments of the Central Basin. The shoreface sandstones are poor in organic matter, suggesting that suspension feeding was the preferred strategy of $O$. cf. nodosa, as is the case with the modern Calianassa major.

The Firkanten Formation comprises the third order Kolthoffberget $\mathrm{T}-\mathrm{R}$ sequence. In middle reaches of the Central Basin, the Ophiomorpha-bearing sandstones were deposited in the final phase of the transgressive systems tract which terminated the underlying paralic system and coal formation. In northern parts of the basin, Ophiomorpha is observed between coal seams and indicates an initial transgressive surface. According to these observations, the presence of Ophiomorpha in the Kolthoffberget $\mathrm{T}-\mathrm{R}$ sequence signals intermittent transgressions into a paralic succession, as well as a major flooding event terminating the paralic system.

The morphology of the Spitsbergen ophiomorphids shows close similarities to $O$. nodosa and $O$. irregularie, but also reveals significant differences. These relationships warrant closer scrutiny and documentation of the Spitsbergen forms to define their exact taxonomy at ichnospecies level. 


\section{Acknowledgements}

Funding of this research was provided by Project CGL2012-33281 (Secretaría de Estado de I + D + I, Spain), Project RNM-3715 (Ramón y Cajal Program), Project RYC-2009-04316 (Ramón y Cajal Program) and Research Group RNM-178 (Junta de Andalucía). The authors are indebted to geology students at the University Centre of Svalbard for helpful assistance in the field. Thanks are extended to Sverre Ola Johnsen for inspiring discussions during several field trips to Spitsbergen and to Atle Mørk for information about field observations of Ophiomorpha.

\section{References}

Boyd C., McIlroy D., Herringshaw L.G. \& Leaman M. 2012. The recognition of Ophiomorpha irregulaire on the basis of pellet morphology: restudy of material from the type locality. Ichnos: An International Journal for Plant and Animal Traces 19, 185-189.

Bromley R.G. 1991. Zoophycos: strip mine, refuse dump, cache or sewage farm? Lethaia 24, 460-462.

Bromley R.G. 1996. Trace fossils: biology, taphonomy and applications, 2nd edn. London: Chapman and Hall.

Bromley R.G. \& Ekdale A.A. 1998. Ophiomorpha irregulaire (trace fossil): redescription from the Cretaceous of the Book Cliffs and Wasatch Plateau, Utah. Journal of Paleontology 72, 773-778.

Bromley R.G. \& Pedersen G.K. 2008. Ophiomorpha irregulaire, Mesozoic trace fossil that is either well understood but rare in outcrop or poorly understood but common in core. Palaeogeography, Palaeoclimatology, Palaeoecology 270, 295-298.

Buatois L.A. \& Mángano G. 2011 . Ichnology. Organism-substrate interactions in space and time. Cambridge: Cambridge University Press.

Cui Y., Kump L.R., Ridgwell A.J., Charles A.J., Junium C.K., Diefendorf A.F., Freeman K.H., Urban N.M. \& Harding I.C. 2011. Slow release of fossil carbon during the PalaeoceneEocene Thermal Maximum. Nature Geoscience 4, 481-485.

Dallmann W.K., Midbø P.S., Nøttvedt A. \& Steel R.J. 1999. Tertiary lithostratigraphy. In W.K. Dallmann (ed.): Lithostratigraphic lexicon of Svalbard. Pp. 215-263. Tromsø: Norwegian Polar Institute.

de Gibert J.M., Netto R.G., Tognoli F.M.W. \& Grangeiro M.E. 2006. Commensal worm traces and possible juvenile thalassinidean burrows associated with Ophiomorpha nodosa, Pleistocene, southern Brazil. Palaeogeography, Palaeoeclimatology, Palaeoecology 230, 70-84.

Ekdale A.A. 1992. Muckraking and mudslinging: the joys of deposit-feeding. In C.G. Maples \& R.W. West (eds.): Trace fossils, short courses in Paleontology 5. Pp. 145-171. Knoxville: Paleontological Society.

Embry A.F. 2009. Practical sequence stratigraphy. Calgary: Canadian Society of Petroleum Geologists.

Fischer-Ooster C. 1858. Die fossilen Fucoiden der Schweizer Alpen, nebst Erörterungen über deren geologisches Alter. (The fucoids of the Swiss Alps, with a closer discussion of their geological age.) Bern: Huber.

Frey R.W. 1975. The realm of ichnology, its strengths and limitations. In R.W. Frey (ed.): The study of trace fossils. Pp. 13-38. New York: Springer.

Frey R.W., Howard J.D. \& Pryor W.A. 1978. Ophiomorpha: its morphologic, taxonomic, and environmental significance. Palaeogeography, Palaeoclimatology, Palaeoecology 23, 199-229.

Harland W.B. 1997. The geology of Svalbard. London: Geological Society.

Howard J.D. \& Frey R.W. 1984. Characteristic trace fossils in nearshore to offshore sequences, Upper Cretaceous of east-central Utah. Canadian Journal of Earth Science 21, 200-219.

Keij A.J. 1965. Miocene trace fossils from Borneo. Paläontologische Zeitschrift 39, 220-228.

Kellogg H.E. 1975. Tertiary stratigraphy and tectonism in Svalbard and continental drift. American Association of Petroleum Geologists Bulletin 59, 465-485.

Książkiewicz M. 1977. Trace fossils in the Flysch of the Polish Carpathians. Palaeontologia Polonica 36. Warsaw: Institute of Paleobiology, Polish Academy of Sciences.

Lundgren B. 1891. Studier öfver fossilförande lösa block. (Studies of fossil-bearing loose blocks.) Geologiska Föreningen i Stockholm Förhandlinger 13, 111-121.

Major H. \& Nagy J. 1972. Geology of the Adventdalen map area. Norsk Polarinstitutt Skrifter 138, 1-58.

Manum S.B. \& Throndsen T. 1986. Age of Tertiary formations on Spitsbergen. Polar Research 4, 103-131.

McNeil D.H. 1990. Tertiary marine events of the BeauforthMackenzie Basin and correlation of Oligocene to Pliocene marine outcrops in Arctic North America. Arctic 43, 301-313.

McNeil D.H. 1997. New foraminifera from the Upper Cretaceous and Cenozoic of the Beaufort-Mackenzie Basin of Arctic Canada. Special Publication 35. Tulsa: Cushman Foundation for Foraminiferal Research.

Miller M.F., Curran H.A. \& Martino R.L. 1998. Ophiomorpha nodosa in tidal estuarine sands of the Calvert Formation (Miocene) of Delaware. In R.N. Benson (ed.): Geology and paleontology of the Lower Miocene. Pollack Farm fossil site, Delaware. Delaware Geological Survey Special Publication 21. Pp. 41-46. Newark, DE: University of Delaware.

Mude S.N. 2011. Paleoenvironmental significance of ichnofossils from the Chaya Formation, Porbandar Group, southwest coast of India. Greener Journal of Physical Sciences $1,29-36$.

Nagy J. 2005. Delta-influenced foraminiferal facies and sequence stratigraphy of Paleocene deposits of Spitsbergen. Palaeogeography, Palaeoclimatology, Palaeoecology 222, 161-179.

Nagy J., Jargvoll D., Dypvik H., Jochmann M. \& Riber L. 2013. Environmental changes during the Paleocene Eocene Thermal Maximum in Spitsbergen as reflected by benthic foraminifera. Polar Research 32, article no. 19737, doi: http:// dx.doi.org/10.3402/polar.v32i0.19737

Nagy J., Kaminski M.A., Kuhnt W. \& Bremer M. 2000. Agglutinated foraminifera from neritic to bathyal facies in 
the Paleogene of Spitsbergen and the Barents Sea. In M.B. Hart et al. (eds.): Proceedings of the Fifth International Workshop on Agglutinated Foraminifera. Grzybowski Foundation Special Publication 7. Pp. 333-361. Krakow: Grzybowski Foundation.

Nagy J. \& Murray J.W. 2011 . Paralic foraminiferal assemblages from the Paleocene Firkanten Formation of Spitsbergen. In M.A. Kaminski \& S. Filipescu (eds.): Proceedings of the Eighth International Workshop on Agglutinated Foraminifera. Grzybowski Foundation Special Publication 16. Pp. 137-149. Krakow: Grzybowski Foundation.

Nøttvedt A. 1985. Askeladden delta sequence (Paleocene) on Spitsbergen - sedimentation and controls on delta formation. Polar Research 3, 21-48.

Pickett T.E., Kraft J.C. \& Smith K. 1971. Cretaceous burrowsChesapeake and Delaware Canal, Delaware. Journal of Paleontology 45, 209-211.

Pryor W.A. 1975. Biogenic sedimentation and alteration of argillaceous sediments in shallow marine environments. Geological Association of America Bulletin 86, 1244-12454.

Rodríguez-Tovar F.J. 2010. Ichnological analysis and sequence stratigraphy research: present-day and prospective. Memoir Geological Society of India 75, 99-114.

Steel R.J., Dalland A., Kalgraf K. \& Larsen V. 1981. The central Tertiary basin of Spitsbergen-sedimentary development in a sheared margin basin. In J.W. Kerr \& A.J. Fergusson (eds.): Geology of the North Atlantic borderlands. Memoir 7. Calgary: Canadian Society of Petroleum Geologists.

Steel R.J., Gjelberg J., Helland-Hansen W., Kleinsphen K., Noettvedt A. \& Rye Larsen M. 1985. The Tertiary strike-slip basins and orogenic belt of Spitsbergen. In K.T. Biddle $\delta$ N. Christie-Blick (eds.): Strike-slip deformation, basin formation and sedimentation. Special Publication 37. Pp. 339-359. Tulsa: Society of Economic Paleontologists and Mineralogists.

Tchoumachenko P. \& Uchman A. 2001. The oldest deepsea Ophiomorpha and Scolicia and associated trace fossils from the Upper Jurassic-Lower Cretaceous deep-water turbidite deposits of SW Bulgaria. Palaeogeography, Palaeoclimatology, Palaeoecology 169, 85-99.

Ter P.C. \& Buckeridge J.S.J.S. 2012. Ophiomorpha beaumarisensis isp. nov., a trace fossil from the late Neogene Beaumaris Sandstone is the burrow of a thalassinidean lobster. Proceedings of the Royal Society of Victoria 124, 223-231.

Uchman A. 1998. Taxonomy and ethology of flysch trace fossils: a revision of the Marian Ksiazkiewicz collection and studies of complementary material. Annales Societatis Geologorum Poloniae 68, 105-218.

Uchman A. 1999. Ichnology of the Rhenodanubian Flysch (Lower Cretaceous-Eocene) in Austria and Germany. Beringeria 25, 67-173.

Uchman A. 2009. The Ophiomorpha rudis ichnosubfacies of the Nereites ichnofacies: characteristics and constraints. Palaeogeography, Palaeoclimatology, Palaeoecology 276, 107-119.

Van Wagoner J.C., Posamentier H.W., Mitchum R.M., Vail P.R., Sarg J.F., Loutit T.S. \& Hardenbol J. 1988. An overview of the fundaments of sequence stratigraphy and key definitions. In K.C. Wilgus et al. (eds.): Sea-level changes: an integrated approach. SEPM Special Publication 42. Pp. 39-45. Tulsa: Society of Economical Paleontologists and Mineralogists. 